\title{
Investigation of the seroprevalence of BoHV-1 and CpHV-1 infections using gB/gE ELISA combination and VNT in selected goat flocks
}

\author{
Merve ÖZGÜR BAYDIN ${ }^{1 *}$, Seval BİLGE DAĞALP² \\ ${ }^{1}$ Etlik Veterinary Control Central Research Institute; ${ }^{2}$ Ankara University, Faculty of Veterinary Medicine, Department of Virology, \\ Ankara.
}

\begin{abstract}
Summary: In this study, we have investigated the seroprevalence of alphaherpesvirus (BoHV-1 and CpHV-1) infections in selected goat flocks using glycoprotein B (gB)/glycoprotein E (gE) ELISA combination and virus neutralisation test (VNT). For this purpose, we collected blood serum samples of 546 Saanen goats from Bolu province and tested them by ELISA and VNT. Using ELISA, 32.05\% (175/546) of the samples were found to be $\mathrm{gB}(+) / \mathrm{gE}(-)$ for $\mathrm{CpHV}-1$, whereas only $0.73 \%(4 / 546)$ of the samples were noted to be $\mathrm{gB}(+) / \mathrm{gE}(+)$ for BoHV-1 releated infection. By performing VNT, we found $31.86 \%(174 / 546)$ and 3.29\% (18/546) positivity for CpHV-1 and BoHV-1, respectively. In conclusion, prevalence of CpHV-1 infection was found to be higher than BoHV1 infection in sampled goat flocks. For diagnosis of alphaherpesviruses in the goats, use of gB blocking ELISA test was found to be favorable as an alternative method. On the other hand, to distinguish between the CpHV-1/BoHV-1, gE blocking ELISA in combination by VNT was found to be incompatible with the statistical analysis $(\mathrm{p}<0.001)$. Considering antigenic cross-reactions between these viruses, because of the incompatibility of these tests, using a more sensitive/specific method to determine CpHV -1 and BoHV-1 antibodies can be suggested.
\end{abstract}

Keywords: Bovine herpesvirus 1, caprine herpesvirus 1, gB/gE ELISA, goat, virus neutralisation test.

\section{Seçilen keçi sürülerinde gB/gE ELISA kombinasyonu ve VNT kullanılarak BoHV-1 ve CpHV-1 enfeksiyonlarının seroprevalansının araştırılması}

Özet: $\mathrm{Bu}$ çalışmada, seçilmiş keçi sürülerinde BoHV-1 ve CpHV-1 enfeksiyonlarının seroprevalans1 glikoprotein B (gB)/ glikoprotein E (gE) ELISA kombinasyonu ve virus nötralizasyon testi (VNT) kullanılarak araştırılmıştır. Bu amaçla, Bolu ilinden 546 Saanen keçisinden alınan kan serumu örnekleri ELISA ve VNT kullanılarak test edilmiştir. Her iki ELISA sistemi ile test edilen örneklerin \%32.05'i (175/546) CpHV-1 antikor pozitifliğini yansitan gB(+)/gE(-) olarak bulunurken, \% 0.73'ü (4/546) BoHV-1 antikorları yönünden pozitifliği yansıtan $\mathrm{gB}(+) / \mathrm{gE}(+)$ olarak belirlenmiştir. VNT ile serumların \%31.86' s1 (174/546) CpHV-1, \%3.29'u (18/546) BoHV-1 antikorları yönünden pozitif olarak değerlendirilmiştir. Sonuç olarak, örneklenen keçi sürülerinde CpHV1 enfeksiyonu prevalansı, BoHV-1 enfeksiyonundan yüksek bulunmuştur. Keçilerde alphaherpesvirus enfeksiyonlarının tanısında gB blocking ELISA alternatif test olarak kullanılabillir bulunmuş, ancak CpHV-1 ve BoHV-1 ayrımında gE blocking ELISA ve VNT kombinasyonunun kullanılması istatisitiksel $(\mathrm{p}<0.001)$ olarak uygun bulunmamıştır. Bu viruslar arasındaki antijenik çaprazreaksiyonları göz önünde bulundurarak, bu testlerdeki uyumsuzluklardan dolayı, CpHV-1 ve BoHV-1 antikorlarının belirlenmesi amacıyla daha hassas ve spesifik metotların geliştirilmesi önerilmektedir.

Anahtar sözcükler: gB/gE ELISA, keçi, keçi herpesvirus 1, sığır herpesvirus 1, virus nötralizasyon testi.

\section{Introduction}

Ruminant alphaherpesviruses can cause infections in the animals in a host-dependent manner. In many countries all around the world, one of the most important viral diseases in cattle, which is responsible for substantial of economic losses, is Bovine herpesvirus 1. This virus causes three significant diseases including; infectious bovine rhinotracheitis (IBR), infectious pustular vulvovaginitis (IPV), and infectious pustular balanoposthitis (IPB). During different researches, some ruminant alphaherpesviruses that related to BoHV-1 have been isolated and their characteristics were reported. One of these related viruses is caprine herpesvirus 1 (CpHV1 ), that causes systemic disease in the offspring of goats, and abortion due to genital diseases in adult goats $(18,23$, 24).

During the last few years, due to antigenic similarities and cross antibody reactions of the BoHV-1 and other ruminant alphaherpesviruses, detecting antibody responses of these viruses has been a controversial issue,

\footnotetext{
* This article was summarized from the master thesis by Merve Özgür Baydın (Ankara University Institute of Health Sciences).
} 
so eradication programs have encountered some difficulties $(12,16,22)$. Also, because the existence of antigenic cross-reactions between these viruses together with their potential ability to cross the species barrier pose theoretical problems in misdiagnosis of $\mathrm{CpHV}-1$ infection due to BoHV-1 infection. In fact, BoHV-1 is rarely able to cause disease in other ruminants like goats. However, sometimes due to close contact between cattle and goats, as in the case of mutual feeding lots, it is possible to assume that this virus can infect goats (25).

Serologic diagnosis of $\mathrm{CpHV}-1$ infection relies on detection of virus neutralizing antibodies in serum. VNT exhibits both high specificity and sensitivity, on the other hand, VNT is expensive, requires 3-4 days, must be performed in well-equipped laboratories by trained personel and most importantly, detects only antibodies with neutralizing activity. To distinguish between BoHV1 and CpHV-1 infections, generally VN tests have been performed. However, because of cross antibody reactions between ruminant alphaherpesviruses, the result of this assay can not be trusted (4).

Although VN and ELISA techniques have a similar sensitivity, ELISA is currently used for serologic diagnosis of several infections because it is a simple, inexpensive, and fast assay that allows the screening of many samples. On the other hand, we can use numerous commercial ELISA kits for BoHV-1, which are based on the $\mathrm{gB}$ and $\mathrm{gE}$ detection systems (11). Among all the herpesviruses, $\mathrm{gB}$ is the most conservative glycoprotein $(17,23)$. In some studies, in spite of long gaps between this glycoprotein in different viruses, motif conservity is noticable. So due to this fact, among ruminant alphaherpesviruses function of $\mathrm{gB}$ is the same (17). Because, the similarities between $\mathrm{gB}$ of BoHV-1 and CpHV-1 have been shown, it is possible to detect antibody responses against $\mathrm{CpHV}-1$ using a gB ELISA kit for BoHV-1. In general, it is suggested using a gB blocking ELISA kit for the diagnosis of ruminant alphaherpesviruses. However, it is impossible to distinguish between these viruses using this method (25). Among ruminant alphaherpesviruses, gE gene has the most antigenic variation. Differences among $\mathrm{gEs}$ of BoHV-1 and CpHV-1 have been clearly shown by many researchers. Researchers reported that $\mathrm{gB} / \mathrm{gE}$ ELISA combination can be used fordetection of $\mathrm{CpHV}-1$ and BoHV -1 in goats based on these properties of $\mathrm{gB}$ and $\mathrm{gE}$ $(22,23,24)$.

In the previous studies that have been performed using VNT in Turkey $(1,2,26)$, presence of these two viruses in goats has been reported. Because of the antigenic cross-reactions between these viruses together with their potential ability to cross the species barrier (14), it is considered that there is a need to determine the accurate prevalence rates of both infection. In addition, according to the clinical findings the effects of economical impact should be investigated in goat flocks. The aim of this study was to investigate seroprevalence of alphaherpesvirus (BoHV-1 and $\mathrm{CpHV}-1$ ) infections using $\mathrm{gB} / \mathrm{gE}$ ELISA combination and VNT comparatively in selected goat flocks.

\section{Materials and Methods}

Blood serum samples, cell culture and viruses: Samples were collected from 20 goat flocks from Bolu province located in Western Black Sea Region of Turkey. By considering $95 \%$ meaningful epidemiologic criteria, 546 goats (4 male and 542 female), aged 6 months or older, were selected and blood samples collected. Clinical semptoms (abortions, stillbirth, drop in milk yield and upper respiratory infections) were detected in XII, XIII, XV and XX flocks. Madin Darby Bovine Kidney (MDBK) cell culture and Cooper strain of BoHV-1 used in VNT that were provided from the stock of Ankara University, Faculty of Veterinary Medicine, Virology Department. We used BA-1 strain of CpHV-1 in VNT kindly provided by Dr. Tempesta, Bari/Italy. Titers of viruses were estimated as $10^{5.5} \mathrm{TCID}_{50} / 0.1 \mathrm{ml}$ for BoHV1 and $10^{5.75} \mathrm{TCID}_{50} / 0.1 \mathrm{ml}$ for $\mathrm{CpHV}-1$.

In this study, initially all goat sera samples were tested by $\mathrm{gB} / \mathrm{gE}$ ELISA combination. When interpreting ELISA results; $\mathrm{gB}(+) / \mathrm{gE}(-)$ means sample is CpHV-1 positive, $\mathrm{gB}(+) / \mathrm{gE}(+)$ means sample is BoHV-1 positive $(4,25)$. All samples were tested for both viruses by VNT which is the gold standard test and both of test results were evaluated in comparison.

$g B / g E$ ELISA: To perform ELISA tests, we used a BoHV-1 gB/gE ELISA kit (Herdcheck IBR gB and $\mathrm{gE}$ antibody ELISA, IDEXX) in accordance with manifacturer's protocol.

Virus neutralisation test: VNT was performed for both viruses according to the protocol of Frey and Liess (1971). Briefly, a volume of $50 \mu 1$ of serial 2-fold dilution from 1:2 of heat-inactivated serum samples were added to 2 wells of a 96 well plate, and then $50 \mu 1$ of the diluted viruses with 100 TCID $_{50}$ titer was added to each well. The plate containing virus-serum was placed in incubator at $37^{\circ} \mathrm{C}, \% 5 \mathrm{CO}_{2}$ for 2 hours. After the incubation period, $300,000 \mathrm{cell} / \mathrm{ml}$ MDBK cells were added to each well, and after 3 days, the present CPE effects in the cells were noted. Then, diluted positive serum samples (1:2-1:64) were subjected to $\mathrm{VN}$ for the determination of antibody titer values in the same way.

Statistical analysis: We analyzed statistically the results of VNT and gB/gE ELISA for CpHV-1 and BoHV1 using SPSS (SPSS Inc., Chicago, IL, United States for Windows 11.5 packet program). 


\section{Results}

$g B / g E$ ELISA: According to the results of the ELISA $45 \%(9 / 20)$ of flocks were found to be positive for CpHV1 and/or BoHV-1. From 546 goat samples that were collected, $32.78 \%$ (179/546) of the total were noted to be positive for $\mathrm{CpHV}-1$ and/or BoHV-1 when using the $\mathrm{gB}$ ELISA test. $32.05 \%(175 / 546)$ of samples were found
$\mathrm{gB}(+) / \mathrm{gE}(-)$ for $\mathrm{CpHV}-1$, and $0.73 \%$ (4/546) of samples were found $\mathrm{gB}(+) / \mathrm{gE}(+)$ for BoHV-1. Positive samples of CpHV-1 were found in IV, V, VI, VII, XI, XII, XIII, XVIII and XX flocks, and BoHV-1 were detected in XII and XIII flocks. According to the sampled flocks, positivity rates CpHV-1 and BoHV-1 were $20.80-70.00 \%$ and $2.73-3.77 \%$ of the total, respectively (Table 1).

Table 1. Serum antibody titers distribution and means of CpHV-1 and BoHV-1 in different flocks.

Tablo 1. Farklı sürülerde CpHV-1 ve BoHV-1 serum antikor titresi dağıllımları ve ortalamaları.

\begin{tabular}{|c|c|c|c|c|c|c|c|c|}
\hline \multirow[b]{2}{*}{$\begin{array}{l}\text { Flock } \\
\text { No }\end{array}$} & \multirow{2}{*}{$\begin{array}{c}\text { The } \\
\text { number } \\
\text { of tested } \\
\text { serum } \\
\text { samples }\end{array}$} & \multirow[b]{2}{*}{ Housing } & \multicolumn{3}{|c|}{ CpHV-1 } & \multicolumn{3}{|c|}{ BoHV-1 } \\
\hline & & & $\begin{array}{c}\text { VNT(+) } \\
\text { samples } \\
(\%)\end{array}$ & $\begin{array}{c}\text { Antibody titer } \\
\text { means }\end{array}$ & $\begin{array}{c}\mathrm{gB}(+) / \\
\mathrm{gE}(-) \text { samples } \\
(\%)\end{array}$ & $\begin{array}{c}\text { VNT(+) } \\
\text { samples } \\
(\%)\end{array}$ & $\begin{array}{l}\text { Antibody titer } \\
\text { means }\end{array}$ & $\begin{array}{c}\mathrm{gB}(+) / \mathrm{gE}(+) \\
\text { samples } \\
(\%)\end{array}$ \\
\hline I & 7 & $\mathrm{~A}$ & - & & - & - & & - \\
\hline II & 20 & A & - & & - & - & & - \\
\hline III & 10 & A & - & & - & - & & - \\
\hline IV & 11 & $\mathrm{D}$ & $\begin{array}{c}5 \\
(45.45)\end{array}$ & $1: 26.80$ & $\begin{array}{c}4 \\
(36.36)\end{array}$ & - & & - \\
\hline $\mathrm{V}^{*}$ & 26 & $\mathrm{D}$ & $\begin{array}{c}11 \\
(42.30)\end{array}$ & $1: 27.72$ & $\begin{array}{c}11 \\
(42.30)\end{array}$ & - & & - \\
\hline VI* & 30 & $\mathrm{D}$ & $\begin{array}{c}21 \\
(70.00)\end{array}$ & $1: 18.57$ & $\begin{array}{c}21 \\
(70.00)\end{array}$ & - & & - \\
\hline VII & 30 & $\mathrm{D}$ & $\begin{array}{c}25 \\
(83.33)\end{array}$ & $1: 32.56$ & $\begin{array}{c}20 \\
(66.60)\end{array}$ & $\begin{array}{c}2 \\
(6.60)\end{array}$ & $1: 4.5$ & - \\
\hline VIII & 21 & A & - & & - & - & & - \\
\hline IX & 66 & A & - & & - & - & & - \\
\hline$X$ & 12 & A & - & & - & - & & - \\
\hline XI & 24 & $\mathrm{D}$ & $\begin{array}{c}5 \\
(20.83)\end{array}$ & $1: 42.80$ & $\begin{array}{c}5 \\
(20.80)\end{array}$ & - & & - \\
\hline XII & 73 & B & $\begin{array}{c}44 \\
(60.27)\end{array}$ & $1: 29.50$ & $\begin{array}{c}45 \\
(61.64)\end{array}$ & $\begin{array}{c}4 \\
(5.47)\end{array}$ & $1: 3.25$ & $\begin{array}{c}2 \\
(2.73)\end{array}$ \\
\hline XIII & 53 & $\mathrm{C}$ & $\begin{array}{c}35 \\
(66.03)\end{array}$ & $1: 40.28$ & $\begin{array}{c}34 \\
(64.15)\end{array}$ & $\begin{array}{c}7 \\
(13.20)\end{array}$ & $1: 3.42$ & $\begin{array}{c}2 \\
(3.77)\end{array}$ \\
\hline XIV & 28 & B & - & & - & - & & - \\
\hline $\mathrm{XV}$ & 12 & A & - & & - & - & & - \\
\hline XVI & 24 & $\mathrm{D}$ & - & & - & - & & - \\
\hline XVII & 17 & $\mathrm{D}$ & - & & - & - & & - \\
\hline XVIII & 27 & A & $\begin{array}{c}12 \\
(44.44)\end{array}$ & $1: 32.6$ & $\begin{array}{c}16 \\
(59.25)\end{array}$ & $\begin{array}{c}1 \\
(3.70)\end{array}$ & $1: 3$ & - \\
\hline XIX & 20 & A & - & & - & - & & - \\
\hline $\mathrm{XX}^{*}$ & 35 & B & $\begin{array}{c}16 \\
(45.71)\end{array}$ & $1: 30$ & $\begin{array}{c}19 \\
(54.28)\end{array}$ & $\begin{array}{c}4 \\
(11.42)\end{array}$ & $1: 3$ & - \\
\hline Total & 546 & & $\begin{array}{c}174 \\
(31.86)\end{array}$ & $1: 31.20$ & $\begin{array}{c}175 \\
(32.05)\end{array}$ & $\begin{array}{c}18 \\
(3.29)\end{array}$ & $1: 3.43$ & $\begin{array}{c}4 \\
(0.73)\end{array}$ \\
\hline
\end{tabular}

A: Closed; B: Open barn, Mutual feeding area; C: Closed, Simultaneously feeding; D: Semi-open barn

*: The flocks which have male goats.

A: Kapalı; B: Açık ağıl, Ortak mera; C: Kapalı, Birlikte beslenme; D: Yarı açık ağıl

*: Erkek keçilerin olduğu sürüler. 
Table 2. Evaluation of ELISA positive animals for BoHV-1 infection together with the results of CpHV-1 and BoHV-1 VNT.

Tablo 2. BoHV-1 enfeksiyonu yönünden ELISA pozitif hayvanların CpHV-1 ve BoHV-1 VNT sonuçları ile birlikte değerlendirilmesi.

\begin{tabular}{|l|c|c|c|c|c|c|}
\cline { 2 - 7 } \multicolumn{1}{c|}{} & \multicolumn{2}{c|}{ BoHV-1 } & \multicolumn{2}{c|}{ CpHV-1 } & \multicolumn{2}{c|}{ BoHV-1 } \\
\hline Herd No. & gB ELISA & gE ELISA & VNT & SN50 & VNT & SN $_{50}$ \\
\hline XII & + & + & + & $1: 16$ & - & - \\
\hline XII & + & + & + & $1: 8$ & - & - \\
\hline XIII & + & + & + & $1: 48$ & - & - \\
\hline XIII & + & + & + & $>1: 64$ & + & $1: 3$ \\
\hline
\end{tabular}

Table 3. Evaluation of VNT positive animals for BoHV-1 infection together with the results of CpHV-1 VNT and gB/gE ELISA.

Tablo 3. BoHV-1 enfeksiyonu yönünden VNT pozitif hayvanların CpHV-1 VNT ve gB/gE ELISA sonuçları ile birlikte değerlendirilmesi.

\begin{tabular}{|c|c|c|c|c|c|}
\hline \multirow[b]{2}{*}{ Serum no } & \multirow[b]{2}{*}{ Flock No } & \multicolumn{2}{|c|}{ ELISA } & \multicolumn{2}{|c|}{$\mathrm{SN}_{50}$} \\
\hline & & $\mathrm{gB}$ & $\mathrm{gE}$ & CpHV-1 & BoHV-1 \\
\hline 108 & VII & - & - & $>1: 64$ & $1: 3$ \\
\hline 131 & VII & + & - & $>1: 64$ & $1: 6$ \\
\hline 305 & XII & + & - & $>1: 64$ & $1: 3$ \\
\hline 315 & XII & + & - & $>1: 64$ & $1: 3$ \\
\hline 324 & XII & + & - & $1: 32$ & $1: 4$ \\
\hline 327 & XII & + & - & $>1: 64$ & $1: 3$ \\
\hline 331 & XIII & + & - & $>1: 64$ & $1: 3$ \\
\hline 337 & XIII & + & - & $1: 32$ & $1: 3$ \\
\hline 347 & XIII & + & - & $>1: 64$ & $1: 3$ \\
\hline 349 & XIII & + & - & $1: 48$ & $1: 3$ \\
\hline 359 & XIII & + & + & $>1: 64$ & $1: 3$ \\
\hline 363 & XIII & + & - & $>1: 64$ & $1: 3$ \\
\hline 380 & XIII & + & - & $>1: 64$ & $1: 6$ \\
\hline 472 & XVIII & + & - & $1: 64$ & $1: 3$ \\
\hline 512 & $\mathrm{XX}$ & - & - & $1: 48$ & $1: 3$ \\
\hline 516 & $\mathrm{XX}$ & + & - & $1: 64$ & $1: 3$ \\
\hline 518 & $X X$ & + & - & $1: 24$ & $1: 3$ \\
\hline 531 & $\mathrm{XX}$ & + & - & $>1: 64$ & $1: 3$ \\
\hline
\end{tabular}

Virus neutralisation test: According to the results of VNT, positivity for CpHV-1 was determined in 9 of the flocks and also positivity for BoHV-1 was determined in 5 of these flocks. $31.86 \%(174 / 546)$ and $3.29 \%(18 / 546)$ of the serum samples were found to be positive for CpHV1 and BoHV-1, respectively. All antibody positive samples of BoHV-1 were shown to be positive for $\mathrm{CpHV}$ 1. Serum antibody titers mean were 1:18.57-1:42.80 for CpHV-1 and 1:3-1:4.5 for BoHV-1 (Table 1).

Correlation among results of ELISA and VNT: Totally, $190(34.79 \%)$ and 21 (3.84\%) samples were found positive of VNT and/or ELISA for CpHV-1 and BoHV-1, respectively. We found 4 serum samples to be positive for BoHV-1 by $\mathrm{gB} / \mathrm{gE}$ ELISA; by considering the specific antibody against BoHV-1, only one sample was noted to be positive both of ELISA and VNT (Table 2). It was determined that all of the samples which were positive for BoHV-1 antibodies were also positive for $\mathrm{CpHV}-1$ antibodies and serum antibody titers were higher than BoHV-1 antibody levels as a result of the evaluation of 18 samples which were BoHV-1 positive by VNT together with the results of $\mathrm{CpHV}-1 \mathrm{VNT}$ and $\mathrm{gB} / \mathrm{gE}$ ELISA results (Table 3).

Statistical analysis: Use of $\mathrm{gB}$ ELISA as an alternative method to differentiate negative and positive groups determined by VNT for $\mathrm{CpHV}-1$ is found statistically significant and results of CpHV-1 and $\mathrm{gB}$ were found consistent $(\kappa=0.897$ ve $p<0.001)$. However use of $\mathrm{gE}$ ELISA as an alternative method to differentiate negative and positive groups determined by VNT for $\mathrm{CpHV}-1$ is not found statistically significant and noted to be inappropriate as an alternative $(\kappa=0.032$ ve $p=0.010)$. 
Use of $\mathrm{gB} / \mathrm{gE}$ ELISA as an alternative method to differentiate negative and positive groups determined by VNT for BoHV-1 is found statistically significant but BoHV-1 VNT and $\mathrm{gB} / \mathrm{gE}$ results were found inconsistent $(\kappa=0.112$ ve $p=0.010)$. Finally, in the flocks which showed clinical signs including abortion, respiratory system infections, we have found $60.6 \%$ of positivity for CpHV1. At the same time, the positivity rate of animals without any clinical signs was $20.6 \%$ of the total. Given the circumstances, results of the flocks which showed clinical signs are statistically significant and meaningful $(\mathrm{p}<0.001)$.

\section{Discussion and Conclusion}

In the previous studies that have been performed in Turkey, presence of BoHV-1 $(1,2,26)$ and CpHV-1 (27) in goats has been reported. In the aforementioned studies, presence of antibodies against both viruses in goats by VNT was investigated. Because of antigenic crossreactions between these viruses together with their potential ability to cross the species barrier $(3,14)$, it is considered that there is a need to determine the accurate prevalence rates of both infection.

According to the results of ELISA 45\% (9/20) of flocks were found to be positive for CpHV-1 and/or BoHV-1. From 546 goat samples that were collected, $32.78 \%$ (179/546) of the total were noted to be positive for CpHV-1 and/or BoHV-1 when using gB ELISA. 32.05\% $(175 / 546)$ of the samples were found to be $\mathrm{gB}(+) / \mathrm{gE}(-)$ for $\mathrm{CpHV}-1$, whereas only $0.73 \%$ (4/546) of the samples were noted to be $\mathrm{gB}(+) / \mathrm{gE}(+)$ for BoHV-1. By performing a VNT, we found $31.86 \%$ (174/546) and 3.29\% (18/546) positivity for CpHV-1 and BoHV-1, respectively (Table 1). In some other studies performed by VNT, the presence of CpHV-1 in Greece was more than 50\% (10), Italy 30$60 \%(8,21)$, Spain $21 \%(9)$. In Turkey, Yonguç et al. (1990) found $26 \%$ antibody positivity in goats for CpHV1. Seroprevalence values in our study were found as similar to that seen in other relative studies for CpHV-1.

Presence of BoHV-1 infection in goats in some countries has been noted. For instance, seropositivity rates in Nigeria (20), Canada (5), US (7) and Egypt (13) are $11.2 \%, 6.9 \%, 13.2 \%$ and $27.6 \%$, respectively. In Turkey, limited studies had been performed to detect the presence of BoHV-1 infection in goats. Yeşilbağ et al.- in two different studies- $(1,26)$ and Ataseven et al.(2010) found that the prevalence of BoHV-1 infection in goats by VNT was $5.52 \%, 26.6 \%$ and $0.7 \%$, respectively. In this research, seroprevalance rate of BoHV-1 in goats has been found to be $3.29 \%$ by VNT. BoHV-1 is a rare infection in goats, so in this research the low rate of distribution of this virus in the flocks is an expected finding, with the exception of the three flocks in which the goats had close contact with the cattle.
By combining the results of ELISA and VNT, we have found nine flocks to be positive for CpHV-1 (Table 1) and it has been shown that five flocks from these nine flocks were also positive for BoHV-1. Totally, 34.79\% and $3.84 \%$ samples were found positive of VNT and/or ELISA for CpHV-1 and BoHV-1, respectively. From these five, in three flocks we recorded direct contact between goats and cattle, and in other two flocks there had been no contact. In spite of a lack of evidence of close contact between these two flocks, we were able to find $6.60 \%$ and $3.70 \%$ positivity for BoHV-1 by VNT, respectively. It may be considered the cross reaction among CpHV-1 and BoHV-1 antibodies.

In this research, all BoHV-1 seropositive animals were also found as positive for CpHV-1. However, 89\% (156/174) of the goats tested positive only to CpHV-1 antibodies, indicating that in these animals, there were no cross-reactions with BoHV-1. Similar results were reported in previous studies $(19,25)$. Martin et al. (1990) reported that antibodies against $\mathrm{CpHV}-1$ were shown to have no potential to neutralize BoHV-1. However, antibodies against BoHV-1 protected against CpHV-1. Silva et al. (2013) reported that all samples were shown to be positive for BoHV-1 showed positivity for CpHV-1 by VNT at the same time. By performing ELISA and VNT for CpHV-1 we have found a positivity of $87.63 \%$. Through statistical analysis we can support our theory that it is possible to use VNT in relation to gB ELISA.

We found $4(0.73 \%)$ serum samples to be positive for BoHV-1 by gB/gE ELISA; by considering the specific antibody against BoHV-1, only one sample was noted to be positive by both of ELISA and VNT (Table 2). By doing ELISA and/or VNT we have noted that $4.76 \%$ of the samples are positive for BoHV-1. By statistical analysis, we have shown that the results of ELISA and VNT for BoHV-1 have low relations $(\mathrm{p}=0.010)$. To discuss this matter, we can mention some reasons as crossantibody reaction and low sensitivity of gE ELISA (about 70\%) (11).

By comparing the results of antibody titer which was performed for BoHV-1 and CpHV-1 by VNT, out of 18 BoHV-1 positive samples, 13 showed antibody titers of 1:64 and above for CpHV-1, and the rest of the samples demonstrated titers between 1:24-1:48 (Table 3). In the samples that have a highly positive antibody titer of $\mathrm{CpHV}-1$, were generally found positive for BoHV-1.

In our research, some samples have shown $\mathrm{gE}$ ELISA negative results but positivity for antibody response to BoHV-1 by VNT. Nevertheless when same samples are examined for antibody titer against $\mathrm{CpHV}-1$, CpHV-1 titers were found higher than BoHV-1(Table 3). In VNT, if titer of homologous species are higher than that of heterologous species, test results are postulated to be positive (25). We can explain this situation with cross 
antibody reactions in VNT. Due to the problems already mentioned regarding the detection of BoHV-1, in goats it is useful to examine both viruses through VNT to find the BoHV-1 titer. Moreover, in order to distinguish between antibody responses against BoHV-1 and CpHV-1, it is suggested to use serum dilution in VNT beginning with a ratio of 1:8 for BoHV-1. However, we think that further experimental studies should be done to support this result.

Among animals from which we collected blood samples, there were four male goats that were found to be positive of $\mathrm{CpHV}-1$. Antibody positivity titer of the male goats' herds were noted to be $42.30 \%, 70.00 \%$ and $54.28 \%$. Silva et al.(2013) demonstrated that virus can pass through semen, so during control programs for this infection, this way of transmission must be noted. In some flocks, we encountered abortions, stillbirth, drop in milk yield, and upper respiratory infections, and interestingly in these flocks positivity of $\mathrm{CpHV}-1$ is significant and meaningful $(p<0.001)$. It is possible to a correlation between these clinical signs and CpHV-1. However this topic requires further investigation.

Recently, an ELISA system based on this hypothesis has been designed in Italy (www.in3diagnostic.com). However, this study was performed prior to the design of aforementioned ELISA kit.

As a result, when evaluating the results of ELISA and VNT for both of viruses, for detecting presence of alphaherpesviruses in goats, use of gB blocking ELISA test was found to be favorable as an alternative method on the other hand, to distinguish between CpHV-1/BoHV-1 antibodies, gE blocking ELISA in combination by VNT was found to be incompatible with the statistical analysis $(p<0.001)$. Hence a spesific serological test able to detect CpHV-1 with low cross reactivity with other ruminant alphaherpesviruses, is highly desirable. Despite the high sensitivity of VNT, cross-reactivity versus other ruminant alphaherpesvirus glycoproteins may produce doubtful results in relation to which virus is circulating in the population (4). Also, in some studies, use of gB ELISA in the detection of alphaherpesviruses has been shown to be the best serological method. However, we assume that to differentiate between these alphaherpesviruses the design of new methods is necessary, especially considering the antigenic differences in $\mathrm{gE}$ of alphaherpesviruses. In this direction, we can suggest to design a new ELISA based on $\mathrm{gE}$ of $\mathrm{CpHV}-1$. In the future, comparative studies should be made by using ELISA produced against $\mathrm{CpHV}-1$, this leads to the success in differentiating of both infections.

\section{References}

1. Alpay G, Tuncer P, Yesilbag K (2014): Serological distribution of some viral infections in cattle, sheep and goats in an isolated islandecosystem. Vet J Ankara Univ, 61, 43-48.
2. Ataseven VS, Basaran Z, Yılmaz V, et al. (2010): Seroprevalence of parainfluenza virus-3 (PIV-3) and bovine herpesvirus type 1 (BHV-1) infections in goats of Van region. YYÜ Veteriner Fak Derg, 21, 7-9.

3. Berrios PE, Mckercher DG (1975): Characterization caprine herpesvirus. Am J Vet Res, 36, 1755-1762.

4. Bertolotti L, Rosamilia A, Profiti M, et al. (2013): Characterization of caprine herpesvirus 1 (CpHVl) glycoprotein E ve glycoprotein I ectodomains expressed in mammalian cells. Vet Microbiol, 164, 222-228.

5. El-Azhary MA, Roy RS, Frechette JL (1979): Serological evidence of IBR and BVD infection in Caribou (Rangifer tarandus). Vet Rec, 105, 336.

6. Frey HR, Liess B (1971): Vermehrungskinetik und Verwendbarkeit einer stark zytopathogenen VD-MD Virusstammes für diagnostische Untersuchungen mit der mikrotiter-Methode. Zentbl Vet Med, 18, 61-71.

7. Fulton RW, Briggs RE, Payton ME, et al. (2004): Maternally derived humoral immunity to bovine viral diarrhea virus $(B V D V)$ 1a, BVDV1b, BVDV2, bovine herpesvirus-1, parainfluenza-3 virus bovine respiratory syncytial virus, Mannheimia haemolytica and Pasteurella multocida in beef calves, antibody decline by half-life studies and effect on response to vaccination. Vaccine, 22, 643-649.

8. Guercio A, Greco G, Lanizzoto G, et al. (1998): Valutazione della diffusione di anticorpi anti Herpes Virus della capra in allevamenti caprini della Sicilia. Atti. SIPAOC, 12, 138-142.

9. Keuser V, Espejo-Serrano J, Schynts F, et al. (2004): Isolation of caprine herpesvirus type 1 in Spain. Vet Rec, 154, 395-399.

10. Koptopoulos G, Papanastasopoulou M, Papadopoulos O, et al. (1988): The epizootology of caprine herpesvirus $(B H V-6)$ infections in goat populations in Greece. Comp Immunol Microb, 11, 199-205.

11. Kramps JA, Banks M, Beer M, et al. (2004): Evaluation of tests for antibodies against bovine herpesvirus 1 performed in national reference laboratories in Europe. Vet Microbiol, 102, 169-181.

12. Lyaku JR, Nettleton PF, Mardsen H (1992): A comparison of serological relationships among five ruminant alphaherpesviruses by ELISA. Arch Virol, 124, 333-341.

13. Mahmoud MA, Ahmed SA (2009): Prevalence of bovine herpesvirus-1 in sheep and goats in Egypt. Lobal Veterinaria Giza, 3, 472-479.

14. Marinaro M, Bellacicco AL, Tarsitano E, et al. (2010): Detection of $C p H V-1$ spesific antibodies in goat sera using an ELISA and SN Test. J Vet Diagn Invest, 22, 245-248.

15. Martin WB, Castrucci G, Frigeri F, et al. (1990): $A$ serological comparison of some animal herpesviruses. Comp Immunol Microbiol Infect Dis, 13, 75-84.

16. Nixon P, Edwards S, White H (1988): Serological comparisons of antigenically related herpesviruses in cattle, red deer and goats. Vet Res Commun, 12, 355-362.

17. Ros C, Belak S (2002): Characterization of the glycoprotein B gene from ruminant alphaherpesviruses. Virus Genes, 24, 99-105. 
18. Saito JK, Gribble DH, Berrios PE, et al. (1974): A new herpesvirus isolate from goats: Preliminary report. Am J Vet Res, 35, 847-848.

19. Silva MLCR, Pituco EM, Nogueira AHC, et al. (2013): Serological evidence and risk factors associated cith caprine herpesvirus 1 in dairy goat flocks in a semiarid region of northeastern Brazil. J Vet Diagn Invest, 25, 125.

20. Taylor J. Herbert (1977): Increase in DNA replication sites in cells held at the beginning of $S$ phase. Chromosoma, 62, 291-300.

21. Tempesta M, Cavalli A, Voigt V, et al. (1994): Presenza di anticorpi per caprine herpesvirus 1 (CapHV.1) in allevamenti caprini dell'Italia meridionale. Atti. SIPAOC, 11, 121-122.

22. Thiry J, Keuser V, Muylkens B, et al. (2006a): Ruminant alphaherpesviruses related to bovine herpesvirus 1. Vet Res, 37, 169-190.

23. Thiry J, Tempesta M, Camero M, et al. (2007): Clinical protection against caprine herpesvirus 1 genital infection by intranasal administration of a live attenuated glycoprotein Enegative bovine herpesvirus 1 vaccine. BMC Vet Res, 3, 33.
24. Thiry J, Tempesta M, Camero M, et al. (2006b): A live attenuated glycoprotein E negative bovine herpesvirus 1 vaccine induces a partial cross-protection against caprine herpesvirus 1 infection in goats. Vet Microbiol, 113, 303308.

25. Thiry J, Saegerman C, Chartier C, et al. (2008): Serological evidence of caprine herpesvirus 1 infection in Mediterranean France. Vet Microbiol, 128, 261-268.

26. Yeşilbağ K, Bilge Dağalp S, Okur Gümüşova $\mathbf{S}$, et al. (2003): Studies on Herpesvirus Infections of Goats in Turkey: Prevalence of Antibodies to Bovine herpesvirus 1. Rev Med Vet, 154, 772-774.

27. Yonguç AD, Akçora A, Vural B (1990): Serological and etiological studies on caprine herpesvirus infection. Project No: Tubitak, VHAG-756.

Geliş tarihi: 11.05.2016 / Kabul tarihi: 22.10.2016

Adress for correspondence:

Merve Özgür Baydin,

Veterinary Control Central Research Institute,

Ankara, Turkey.

e-mail:merveozgur87@gmail.com 